\title{
Erratum to: The Phase Stabilities of Magnesium Hydroxychlorides
}

\author{
JAN DE BAKKER, JOSHUA LAMARRE, JOHN PEACEY, and BOYD DAVIS
}

DOI: $10.1007 / \mathrm{s} 11663-012-9793-5$

(C) The Minerals, Metals \& Materials Society and ASM International 2013

\section{Erratum to: METALLURGICAL AND MATERIALS TRANSACTIONS B, Vol. 43B, pp. 758-63 DOI: $10.1007 / \mathrm{s} 11663-012-9673-\mathrm{z}$}

THE authors have noted a number of errors in the article which they would like to correct here. We apologize for confusion that may have arisen as a result of these errors.

Author affiliations (p. 758)

"JOHN PEACEY, Professor, and BOYD DAVIS, Associate Professor, are with the Department of Mining Engineering, Queen's University."

Should read:

"John Peacey is a professor in the Department of Mining Engineering, Queen's University, Kingston, Ontario, Canada. Boyd Davis is a principal with Kingston Process Metallurgy, Inc., Kingston, Ontario, Canada."

p. 759, Column 2, Paragraph 4

"Run $9 / 23-1$ was performed at $363 \mathrm{~K}\left(90{ }^{\circ} \mathrm{C}\right)$; for run $9 / 23$, the brine was heated to $363 \mathrm{~K}\left(90^{\circ} \mathrm{C}\right)$ during $\mathrm{MgO}$ dissolution but was maintained at $348 \mathrm{~K}\left(75^{\circ} \mathrm{C}\right)$ after filtration."

Should read:

"Run 9/23-1 was performed at $363 \mathrm{~K}\left(90^{\circ} \mathrm{C}\right)$; for run $9 / 23-2$, the brine was heated to $363 \mathrm{~K}\left(90^{\circ} \mathrm{C}\right)$ during $\mathrm{MgO}$ dissolution but was maintained at $348 \mathrm{~K}\left(75^{\circ} \mathrm{C}\right)$ after filtration."
JAN DE BAKKER, Metallurgist, is with BBA, Inc., 630, boul. Rene-Levesque O, Suite 2500, Montreal, QC H3B 1S6, Canada. Contact e-mail: debakker.jan@gmail.com JOSHUA LAMARRE was formerly an Undergraduate Student with the Department of Chemical Engineering, Queen's University, Kingston, ON K7L 3N6, Canada. JOHN PEACEY, Professor, is with the Department of Mining Engineering, Queen's University. BOYD DAVIS, Principal, is with Kingston Process Metallurgy, Inc., 759 Progress Ave., Kingston, ON K7M 6N6, Canada.

The online version of the original article can be found under doi: 10.1007/s11663-012-9673-z.

Article published online February 23, 2013.
Table I (p. 760)

The temperatures in the left-hand column of the table were incorrectly converted to Kelvin during editing

\begin{tabular}{llc}
\hline Temperature $\left[\mathrm{K}\left({ }^{\circ} \mathrm{C}\right)\right]$ & & Temperature $\left[\mathrm{K}\left({ }^{\circ} \mathrm{C}\right)\right]$ \\
\hline$-138(135)$ & should read & $408(135)$ \\
$-163(110)$ & should read & $383(110)$ \\
$-173(100)$ & should read & $373(100)$ \\
$-183(90)$ & should read & $363(90)$ \\
$-193(80)$ & should read & $353(80)$ \\
\hline
\end{tabular}

Table II (p. 761)

Temperatures were incorrectly converted to Kelvin during editing.

Caption reads "Precipitate Analysis of Run 9/23-1

(Precipitation at $-183 \mathrm{~K}\left[90^{\circ} \mathrm{C}\right]$ )"

Should read:

"Precipitate Analysis of Run 9/23-1 (Precipitation at $\left.363 \mathrm{~K}\left[90^{\circ} \mathrm{C}\right]\right)$ ",

Table III (p. 761)

Temperatures were incorrectly converted to Kelvin during editing.

Caption reads "Precipitate Analysis of Run 9/23-2 (Precipitation at $-198 \mathrm{~K}\left[75^{\circ} \mathrm{C}\right]$ )"

Should read:

"Precipitate Analysis of Run 9/23-2 (Precipitation at $348 \mathrm{~K}\left[75^{\circ} \mathrm{C}\right]$ )"

p. 761, column 1, paragraph 3

"The $\mathrm{Mg}(\mathrm{OH})_{2} / 3$-form boundary, in contrast, has been taken from literature values that have a significant scatter, and the authors have drawn the boundary at the left edge of the scattered points, between the points 10.62 pet $\mathrm{MgCl}_{2},-248 \mathrm{~K}\left(25^{\circ} \mathrm{C}\right)$ from Bury and Davies $^{10]}$ and 14.01 pct $\mathrm{MgCl}_{2}, 323 \mathrm{~K}\left(50{ }^{\circ} \mathrm{C}\right)$ from Maeda and Yamane. ${ }^{[1]}$

Should read:

"The $\mathrm{Mg}(\mathrm{OH})_{2} / 3$-form boundary, in contrast, has been taken from literature values that have a significant scatter, and the authors have drawn the boundary at the left edge of the scattered points, between the points 10.62 pet $\mathrm{MgCl}_{2}, 298 \mathrm{~K}\left(25{ }^{\circ} \mathrm{C}\right)$ from Bury and Davies $^{[10]}$ and 14.01 pet $\mathrm{MgCl}_{2}, 323 \mathrm{~K}\left(50{ }^{\circ} \mathrm{C}\right)$ from Maeda and Yamane. ${ }^{[1]}$ 